JSM (10) (2)
JURNAL SENI MUSIK

\title{
Hadrah Ishari Art: Ethnomusicological Study At Sirojul Huda Islamic Boarding School In Purwosari Pasuruan Regency
}

\author{
Bunga Widiya Larashati ${ }^{\varpi 1}$ \\ Universitas Negeri Surabaya \\ Setyo Yanuartuti ${ }^{\bowtie 2}$ \\ Universitas Negeri Surabaya \\ I Nyoman Lodra \\ Universitas Negeri Surabaya
}

Article Info Abstract

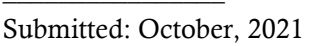

Revised : November, 2021

Accepted:December,2021

This research aims to analyze the ethnomusicological study of hadrah ishari musical art. The type of research used is descriptive qualitative with an ethnomusicological approach. The data collection techniques are through observation, interviews, and documentation. Interviews were done with an informant who is competent in the art of hadrah ishari is Ichwan Mu'jizat. The data analysis steps are data reduction, presentation, and conclusions. The data validity was obtained through triangulation techniques of data sources and techniques.

Keywords:

History, Presentation Form, Elements of Music,

Functions of Music

The results of the study show history, the form of presentation of this hadrah music consists of the introduction, the core, and the final presentation. The elements that make hadrah ishari music consist of tempos, rhythm, expressions, dynamics, and tone scales, while the elements that make the vocals of hadrah music are articulation, respiration, intonation, and tones. The movement of the head and hands also has a deep meaning about the symbol writing of Allah SWT and Muhammad SAW. The function of hadrah ishati itself has developed from the beginning for da'wah media, now it has begun to develop into entertainment, communication, commercial and creative media. Based on the results of the research, it is hoped that there are further researches and they can improve the results of the research, especially in the ethnomusicology study of the hadrah musical art.

\footnotetext{
Corresponding Author: 


\section{INTRODUCTION}

Indonesia is one of the countries that has various special cultures, one of which is art. Art is part of a culture that must be preserved because art itself has become a part of human life. Art is inherited hereditarily to the next generation with a hope that the value contained in the art can be preserved. Along with the development of the times, arts start less popular with teenagers because of the lack of meaning contained in arts in every region.

Pasuruan is one of the regions in East Java, Indonesia which has some unique regional arts. Pasuruan is also known as the city of santri, kinds of regional arts place more emphasis on art that breathes religion where the traditional arts will be passed down from generation to generation. Therefore, it isn't eroded by the times and the arts are preserved. In the article, Prestisa (2013) states artworks reflect the identity of the community in which they live, in the form of customs or the way of life in an origin.

One of the traditional musical works in Pasuruan is musical arts, especially the musical art of hadrah. In the article Wahyu (2015) Hadrah art is the art of traditional music that sings poems praising Allah SWT and Prophet Muhammad SAW accompanied by a tambourine blow. Hadrah is also defined as a type of song that comes from dzikir and the song is accompanied by a tambourine-style musical instrument that is almost the same as kompang. The role of ishari music is very important for the community in Pasuruan, the development of the art of hadrah ishari can be found in several activities on Islamic days. The more days, the art of hadrah ishari is getting less and less attractive to teenagers, even though the art of Hadrah Ishari is a form of traditional musical art that must be preserved in order not to be eroded by the times. It is following what Hadiwinoto (2002:30) said that preservation will not survive if the community does not support it. Art experts embrace the community to be lovers of traditional art preservation that must be preserved. In addition, the younger generation also does not understand the ethnomusicology of Hadrah Ishari music art, movements, and compliment whose music aims to praise Allah SAW and the Prophets with the hope to be interceded. According to the interview results with Ichwan as a hadrah Ishari coach who revealed that the art of hadrah ishari is less attractive to young people because young people nowadays. They prefer modern music with foreign ethnicities. Finally, at the Sirojul Huda Islamic boarding school, they are given time to practice twice a week so that children can appreciate and love traditional music in Indonesia more.

Based on the observation on November $25^{\text {th }}$ in 2021 at the Sirojul Huda Islamic Boarding School, hadrah ishari music presentation has a unique character with tambourine beats, typical vocal characteristics, dance movements, and kinds of hadrah ishari ethnomusicology that are different from other hadrah. Based on the background of the problem above, it becomes the main point that can attract the researcher to raise this ishari music art so that it can be better known to the wider community. In addition, the large number of ISHARI (Hadrah Arts Association of Republic of Indonesia) groups in Pasuruan Regency attracts the researcher to analyze the ethnomusicology of hadrah musical arts.

\section{METHOD}

The type of research used is descriptive qualitative research with the musicology approach. The research study is about the study of ethnomusicology in the art of hadrah ishari at the Sirojul Huda Islamic boarding school, Purwosari, Pasuruan Regency.

This research is conducted at the Sirojul Huda Islamic Boarding School, Polorejo Village, Purwosari Sub-District, Pasuruan Regency. This research subject is a hadrah music performer or player at the Sirojul Huda Islamic boarding school which is chosen according to the problems raised by the researcher. The object of this 
research is about the ethnomusicology of hadrah ishari musical arts.

Data collection techniques are observation, documentation, and interviews. Margono (2003: 158), observation is surveillance and recording systematically to the symptoms appeared on the object of this research. The observation made in this research is the ethnomusicology of hadrah music. The surveillance and recording conducted directly to the object are investigated directly (Keraf, 1994:162).

According to Moleong (1980:148) the interview is a conversation with a certain intention which is carried out by two parties namely the interviewer who submits questions and the informant who provides answers to the questions submitted by the interviewer. The interviews were conducted on Ichwan as the performer of Kadrah Ishari musical arts and students of Sirojul Huda Islamic Boarding School.

Document study technique is the data collection through written heritage, archives, and books about opinions, theories, propositions, or laws related to research problems Margono (2003: 181).

This interview has sources of data which is divided into two sources namely primary data sources and secondary data sources. The secondary data are obtained from documentation and written sources such as books and articles related to the hadrah ishari musical arts. The primary data sources are obtained from the direct interview with an ishari performer, namely Mr. Ichwan Mu'jizat, S.Pd. The activity of data analysis was started from data reduction, data presentation, and conclusion-making.

Data analysis techniques used in this research are the activity of reducing, correcting, and verifying data. The technique of data validity is using triangulation. The meaning of this triangulation is to examine or re-verify the data by using various ways through various sources from various times. According to Sugiyono (2012:274), there are three triangulations, namely source triangulation, technical triangulation, and time. To adjust the research needs, the researcher chose 2 triangulation methods, namely source triangulation, and technical triangulation, as follows:

Source triangulation is a way to verify data using more than one data source, for example by using field observations, interviews, historical documents, books, etc.

Technical triangulation is the method used as a way of verifying data by using more than one method, for example comparing data, interviewing, and related documents used as the references of the research.

\section{RESULT AND DISCUSSION}

ISHARI is a religious social organization founded by K.H Abdurrahim. ISHARI develops so fast in Pasuruan. In 1959, K.H Wahab make a forum for organization and declaration by ishari figures namely Jamiyah Hadrah. When he died, the leadership of $\mathrm{KH}$ Wahab was replaced by his son, namely K.H Muhammad bin Abdurrahim with the change of the name, Jamiyah Hadrah to ISHARI (Hadrah Arts Association of the Republic of Indonesia).

This name change is meant for accommodating jamiyah hadrah more appearing, the use of the word republic in the word ISHARI is also meant to fortify so that jamiyah ISHARI was not infiltrated by the movement of communists. Besides that, the purpose of the ishari establishment is to spread the religion of Islam and the preservation of the traditional musical art in Pasuruan.

In 1961, the Ulama had the idea of masyahii and on the orders of K.H Wahab Hasbullah, Raiss PBNU at that time proposed that IISHARI becomes autonomous body, Nahdatul Ulama (NU). At that time jamiyah ISHARI becomes structured clearly.

The hadrah ishari musical art is unique in the Pasuruan Regency which is growing very rapidly. Helena (Bouvier, 2002:214) by the method of her research states that hadrah ishari is useful for opening the way to get closer to Allah 
SWT by singing the Islamic poems played. The musical art of hadrah ishari is singing Islamic poems using the beats of the tambourine musical instrument which becomes the characteristic of this hadrah musical arts. The form of presenting the hadrah musical art has different musical and vocal compositions with their characters. Hadrah ishari music in Pasuruan Regency has many functions, one of which is for da'wah media by emphasizing the elements of distinctive music. The phenomenon making the researcher appoints the ethnomusicology study of hadrah musical arts in Pasuruan Regency.

Ishari, the art of hadrah, which is characteristic of Pasuruan, has several distinctive mukhud. One of the hadrah ishari music groups that often carries out various activities of ishari is the Sirojul Huda Islamic Boarding School, Purwosari Sub-District. There are kinds of ishari characters in a group.

\section{THE FORM OF PRESENTATION}

The form of presentation is media or tools to communicate, to convey the meaning contained in the form of the musical art itself, or how to convey the specific messages to the recipients (Suwondo, 1992:5). The form of the musical artworks is a musical framework as well as the framework for living beings so it has a big role in the works of musical arts. The form of music arts is also said to be a design of a musical work that has a musical art context so that the concept of music can be seen clearly (Kurniasih, 2006:5). Based on some opinions about the form of musical art presentation above, it can be said that the form of presentation is the framework used to create musical artworks so that there is a clear musical flow. The form of presenting the hadrah ishari musical art at the Sirojul Huda Islamic Boarding School is general, which includes:

\section{a. Introduction - Ibtida' Bisyahri}

Ibtida' means to start. This ibtida' song must be used when starting hadrah ishari music, for example, ibtida' reading is Bassmallah.

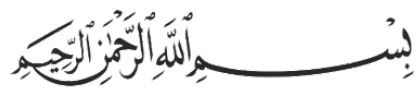

Bassmallah in general has the meaning of intending everything which is conducted in the name of Allah SWT. Bassmallah can also be interpreted as a strand of prayers to ask for blessing and smoothness for all activities conducted because it's surely Allah SWT is the entirely gracious, the especially merciful.

b. Core-Reading Sholawat

In Amaliyah "Thariqah Mahabbaturrasul", there is something to do by followers to pour their love to Allah SWT and Prophet Muhammad SAW. First, sholawat readings carried out by ISHARI organization Sirojul Huda Islamic Boarding School is reading 2 books, namely Maulid Syaraf Al-Anam as the main reading source and the Diwan Hadrah book as readings about poems used to an answer while doing a Raddat dance. The Maulid Syaraf Al-Anam book contains poems and natsar. The leader of the poems reading is called teacher/Badal Hadi while the one who reads natsar is called Rawi. The reading of Sholawat is addressed to the Prophet Muhammad, which consisted of Muhud Tanaqqalta, Wulidal, Badat Lana.

The Example of Reading: Allah $\mathrm{Hu}$ Allah... Allah Allah Allah...

c. Final - Muhud Maqom or Mahallul Qiyam

Muhud Mahallul Qiyam is a sholawat of the prophet Salam Alaika which contains poems to the Prophet SAW which is very deep. Muhud Mahallul Qiyam is usually read by standing. This reading is read by standing actually as a way of giving respect to the Prophet Muhammad SAW. 


\section{THE ELEMENTS OF MUSIC}

The rhyme of a poem is in ishari hadrah musical arts. The knocks or beats made by the musician contain not only a beat but also philosophical meaning aimed as "thariqoh Mahabbah" that is a love way technique to Allah and the Prophet Muhammad SAW. It means that to master this punch or beat, you must go through the guidance of Guru or Hadi. Jamalus (1981) states that some elements of music that influence music are harmony, rhyme, melodic expression, rhythm, tempos, dynamics, and bars. The second element in music that becomes the basic pattern is the structure of the song and the form of the music. The philosophical explanation of the elements of hadrah ishari music is as follows:

\section{a. Rhythm}

Nur Iqbal's journal states that rhythm is a simple metric relationship which is the basic pattern of music. Rhythm can determine the pattern of melodic rhyme in playing musical instruments, especially in the hadrah ishari musical arts. Every instrument has a different rhythm or rhythmic pattern so that the rhythm will form a distinctive harmonization in hadrah ishari.

\section{1). The Rhythm of Beating Juz}

This rhythm sounds "tak-dik-tak" which means in tune with notation Hu-All-Loh or Lafadz Mu-hammad.

2). The Rhythm of Beating Yahum This rhythm is a symbol "Lailahaillallah" and "Muhammadur-rasulullah". There are three combined notations as follows:

- Krotokan is also called Wedokan has 5 beats "taktak - taktak-dik" that means of practicing the 5 pillars of Islam.

- Penyela (Tengahan), it consists of three beats "Tak-dik-Tak" which means 3 main teachings of Islam. They are Tauhid, Fiqih dan Tasawuf.

\section{3). The Rhythm of Beating}

The philosophy from the rhythm of Tareem beating is the same as Yahum. The Tareem rhythm is a symbol of saying "Lailahaillallah" and "Muhammadur-rasulullah as a symbol of love for the Prophet Muhammad SAW.

\section{b. Tempo}

Tempo is a beat or measure of how fast the song is. In hadrah ishari music, it uses 2 tempos, namely allegro or fast and adagio or slow and expressive tempo.

\section{c. Tone Scale}

Although there is no accompanying melodic music, in hadrah ishari there is a tiered tone scale, for example in the song ibtida'. For example, the note of Mahallul Qiyam has a tone scale

$\begin{array}{lllllll}3 & 3 & 3 & 2 & 3 & 5 & 432\end{array}$

Ya Nabi Salam Alaika

$$
\begin{array}{lllllll}
5 & 4 & 3 & 4 & 3 & 1 & 2
\end{array}
$$

Ya Rosul Salam Alaika

\section{d. Expression}

The way of music players expresses their expressions in playing music is to follow the style of the tambourine. If the beat is hit hard then facial expressions will follow. The body expressions also follow the music.

\section{e. Dynamics}

Dynamics means how quietly or loudly a sound. In hadrah ishari music, this element must also be applied so that the appreciation and signs for starting the dance/Roddat can be understood. If the dynamics go up and there is a shout sign of someone eating. It indicates that the wheel movement will start or end soon. A shout can also be interpreted as giving a code to the Roddat dancer to start or end the dance movement.

f. Bar

Repeated beats in the bar are also applied in the game of tambourine and applied to the rhythm of Juz, Yahum, and Tareem beats. 


\section{THE MUSICAL INSTRUMENT ORGANOLOGY}

An instrument used to play the ishari musical art is a tambourine with a diameter of $28-30 \mathrm{~cm}$.

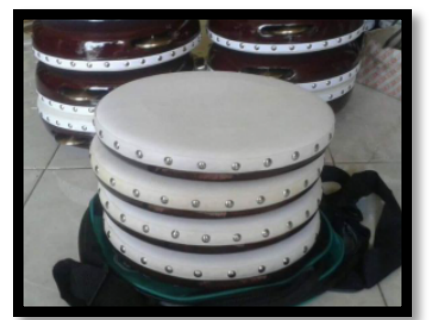

Figure 1 : Hadrah Musical Instrument (Source :Bunga, on October $10^{\text {th }}$ in 2021)

Ishari tambourine is usually made of imbo wood with super quality and from skin scrub from the back of selected cows so it doesn't break easily.

\section{VOCAL}

A vocal is the most important thing in bringing a song so that the meaning contained in the song can be conveyed to the listener. Harahap (1994:38) states using the correct vocal technique helps listeners to understand the meaning of the song. Vocals in ishari music arts also have a distinctive character and a minor diatonic characteristic where the vocal tone tends to be sad and asks for forgiveness and the intercession of Allah SWT and His Prophet. The main vocal focus is applied on reading hadrah ishari which notices breathing techniques.

According to Sihombing (2003:9), some breathing techniques, namely: chest breathing, abdominal breathing, and diaphragmatic breathing. Based on Sihombing (2003:10) states that chest breathing is a technique that involves filling the air in the upper lungs. The breathing technique used in hadrah ishari music tends to use diaphragmatic breathing because there are high and low notes. Good breathing to use is diaphragmatic breathing in which the singer stores air between the chest and abdominal cavities. Diaphragmatic technique is done by the air in the lungs is held without feeling tired so that the exhaled breath can be regularized by the diaphragm and the back muscles of the left and right side (Ritonga, 2003:9).

Articulation can be clear in each makhroj. According to Sihombing (2003:13), Articulation is to change the pronunciation of words or articulation can be set through the oral cavity and the good position of the mouth.

The right intonation in singing the lyrics of the song. According to Ali (2006:51), intonation is related to the singer's ability to sound a tone correctly, in high notes and low. Pronunciation intonation notices sound pressure.

\section{THE DANCE MOVEMENT OF RODDAT}

Rodat comes from the Arabic language that is roddan Yaruddu-roddan means to return, reply and refuse. There are 3 things that a person does when doing Roddat, namely:

1. Replying to the sholawat reading which is read by Guru Hadi

2. Doing the ishari dance movement "Raaqs"

3. Doing "Tashfiq" or the ishari applause

4. Doing "Suluk". In the Tasawuf term, it means sambat maring Gusti Allah

The purpose of Roddat contains the meaning, namely.

1. Echoing tasbih and dzikir to Allah SWT.

2. Creating calm and happiness at the birth of the Prophet Muhammad SAW.

3. Giving applause as a sense of love for the presence of Prophet Muhammad SAW.

4. Minor suluk meant to be used to pray to Allah and ask for prayer to Rasulullah SAW.

Various Roddat movements are divided into two:

1. Roddat of the body with head-nodding movements is equated to the beats of a 
tambourine, and the movements illustrate lafadz "Allah".

2. Roddat of the body with the hand movements describe the lafadz "Muhammad".

\section{THE FUNCTIONS OF ISHARI MUSIC}

In the life of the community in Pasuruan, the art of hadrah ishari has a very important role in community events and religious activities. The people of Pasuruan consider the art of hadrah as a means that must be present in every religious ceremony such as the birthday of the Prophet, moving house, sedekah bumi, and padang bulan rituals. The function of hadrah ishari music greatly influences the community. Previously, hadrah music was usually only used for religious rituals, now the function of hadrah music is very developed and play a role in education, entertainment, communication, and even commercial

Commercial functions are also implemented by the Sirojul Huda Islamic Boarding School where this Islamic Boarding School receives event calls for community or religious activities.

\section{CONCLUSION}

Based on the research results which has been described. it can be concluded that the ethnomusicology of hadrah ishari musical arts is very interesting to understand and help preserve the traditional musical arts.

The form of presentation consisting of ibtida' bisyahri, sholawat in the core, and Muhud Maqom has meanings and values that must be understood by the community.

The musical elements of tempos, rhythm, tone scales, expression, dynamics, bars created from the sound of hadrah musical instruments, Roddat dance, and ishari music vocals have unique characteristics by notice articulation, breathing techniques, and tone scales that have minor diatonic characteristics. Roddat also has several movements that contain the meaning of writing lafadz Allah SWT and Muhammad SAW. The function of hadrah ishari music is now also starting to develop and is not only used as a propaganda medium but also as a commercial, educational, and entertainment medium.

\section{REFERENCES}

Bouvier, Helena.2002.Lebur Seni Musik dan Pertunjukan dalam Masyarakat Madura. Jakarta:Yayasan Obor

Darwis, Harahap.1994.Binaan makna. Selangor: Dewan Bahasa dan Pustaka

Handiwinoto, Wahyu .2002. Pelestarian Budaya Local. Jakarta:PT.Galia Indonesia

Iqbal Nur, Siti Aesijah, Abdul Rachman. 2020. Bentuk Komposisi Musik Tradisional Balo-balo Grub Kampung Tirang di Kecamatan Tegal Barat Kota Tegal. Vol 9 No 2. https://doi.org/10.15294/ism.v 9i2.39205. (Diakses Pada 9 November 2021)

Keraf, Gorys.1994. Komposisi:Sebuah Pengantar Kemahiran Bahasa. Flores: Nusa Indah.

Kurniasih.2006. Pengertian Pengembangan dan Pemanfaatan Musik Tradisional. Jakarta:PT.Grafinda Persada

Margono, S. 2003. Metodologi Peneliyian Pendidikan. .Jakarta: Rineka Cipta

Moleong, Lexy J. 1980. Metodologi Penelitian Kualitatif. Bandung: Remadja Karya CV

Nuruddin. Al-Iqdu Al-Durar Fii Tarjamati al-Shalawati ala an-Nabi li al-Ishari. Surabaya: Pimpinan Wilayah ISHARI Jawa Timur, 2015.

Prestisa, Galuh. Bagus.2014. Bentuk Pertunjukan dan Nilai Estetis 
Kesenian TerbangKEncer Baitussolikhin di Desa Bumijawa Kecamatan Bumijawa Kabupaten Tegal.file:///C:/Users/HP/Dow nloads/9260-Article\%20Text18257-1-10-20160204.pdf. JSM 3(2) (Diakses 9 Nov 2021)

Ritonga, Emil Azman.2003.Teknik Vokal. Jakarta: Badan Pusat Statistik

Sihombing. 2003. Teknik Pernapasan. Jakarta: Balai Pustaka Original

Sugiono, 2012. Metodologi Penelitian Pendidikan. Bandung: Alfabeta

Sumaryanto, Totok.2010. Metodologi Penelitian 2. Semarang:Universitas Negeri Semarang

Suwondo.1992. Seni Pertunjukan Musik Tradisional. Jakarta: Yudistira

Ilaihi, Wahyu \& Harjani Hefni. Pengantar Sejarah Dakwah. Jakarta: Kencana, 2007.

Wahyu, Harpani dkk. 2015.Penerapan Nilai Keagamaan Seni Hadrah Maullatan Al-Habsyi di Kelurahan Pelambuan Kecamatan Banjarmasin Barat. Vol 5 No 9.

https://media.neliti.com/media/ publications/122011-IDpenerapan-nilai-keagamaanmelalui-seni-h.pdf (diakses pada 9 November 2021) 